\title{
The Sensitivity of a Dike-Marsh System to Sea-Level Rise-A Model-Based Exploration
}

\author{
Richard Marijnissen ${ }^{1, *(\mathbb{D}}$, Matthijs Kok ${ }^{2,3}$, Carolien Kroeze ${ }^{1}$ and \\ Jantsje van Loon-Steensma ${ }^{1,2}$ (iD) \\ 1 Water Systems and Global Change group, Wageningen University \& Research, P.O. Box 47, \\ 6700 AA Wageningen, The Netherlands; carolien.kroeze@wur.nl (C.K.); jantsje.vanloon@wur.nl (J.v.L.-S.) \\ 2 Faculty of Civil Engineering and Geosciences, Delft University of Technology, P.O. Box 5048, 2600 GA Delft, \\ The Netherlands; Matthijs.Kok@tudelft.nl \\ 3 HKV Consultants, Botter 11 29, 8232 JN Lelystad, The Netherlands \\ * Correspondence: richard.marijnissen@wur.nl
}

Received: 19 December 2019; Accepted: 10 January 2020; Published: 15 January 2020

\begin{abstract}
Integrating natural components in flood defence infrastructure can add resilience to sea-level rise. Natural foreshores can keep pace with sea-level rise by accumulating sediment and attenuate waves before reaching the adjacent flood defences. In this study we address how natural foreshores affect the future need for dike heightening. A simplified model of vertical marsh accretion was combined with a wave model and a probabilistic evaluation of dike failure by overtopping. The sensitivity of a marsh-dike system was evaluated in relation to a combination of processes: (1) sea-level rise, (2) changes in sediment concentration, (3) a retreat of the marsh edge, and (4) compaction of the marsh. Results indicate that foreshore processes considerably affect the need for dike heightening in the future. At a low sea-level rise rate, the marshes can accrete such that dike heightening is partially mitigated. But with sea-level rise accelerating, a threshold is reached where dike heightening needs to compensate for the loss of marshes, and for increasing water levels. The level of the threshold depends mostly on the delivery of sediment and degree of compaction on the marsh; with sufficient width of the marsh, lateral erosion only has a minor effect. The study shows how processes and practices that hamper or enhance marsh development today exacerbate or alleviate the challenge of flood protection posed by accelerated sea-level rise.
\end{abstract}

Keywords: climate adaptation; flood protection; salt marsh

\section{Introduction}

To protect the growing number of people living in deltas against flooding, flood protection measures are required. In many deltas, "grey" solutions such as dikes, levees, and storm surge barriers have been implemented [1-3]. In general, these measures are designed to function over long periods, yet are relatively inflexible to unforeseen accelerated sea-level rises [2,4-6]. Moreover, many grey solutions can be detrimental to ecosystems by confining the intertidal area (coastal squeeze) or affecting the natural hydro-morphological processes $[2,7,8]$.

Nature-based solutions, where "green" ecosystems aid in flood protection, have recently garnered a great deal of attention [4,5]. Ecosystems like salt marshes promote accretion on the foreshore of a flood defence through interacting with the tide, dampening waves, and attenuate storm surges [9-12]. A major benefit of marsh ecosystems in flood protection is their ability to naturally adapt to sea-level rise under the right conditions $[13,14]$. However, mitigating flood risk with nature-based solutions alone may not always be feasible. As a result, hybrid flood defences, incorporating both traditional flood defences structures and natural elements, are an attractive strategy to protect deltas [4-6]. 
A combination of dikes with salt-marshes is considered to be an effective hybrid flood defence $[4,15,16]$. Yet, the inherent variability and uncertainty about the development of the marsh is an obstacle for implementation in an integrated dike-marsh flood protection scheme where only small risks are acceptable $[3,17]$. Marshes are dynamic systems which expand and retreat periodically in response to the complex interactions between waves, elevation, and seedling establishment $[18,19]$. Furthermore, marshes respond directly to human activities that affect the availability of sediments, such as dredging or upstream dam construction [20,21]. Large uncertainties about the effectiveness of a marsh for flood protection could negate its potential contributions, and preference may be given to a more traditional flood defence rather than to a hybrid flood defence [22].

So far, few studies have tried to translate processes affecting marshes into the required adaptations of dikes. Van Loon-Steensma and Kok [17] qualitatively described the connection between marshes and flood risk reduction concepts. Vuik et al. [23] were the first to apply these concepts for a safety assessment of a flood defence. In Vuik et al. [6], this type of assessment was used to compare the cost-effectiveness of a natural foreshore against regular reinforcement measures with sea-level rise, assuming all other factors governing the marsh would remain constant. In this study, we explore how dike reinforcement is affected in case those factors do not remain constant.

The aim of this study is, therefore, to address how the processes on a natural foreshores affect the future need for dike heightening. More specifically, we consider the effects of sea-level rise, sediment availability, marsh erosion, and compaction on the dike crest elevation in a marsh-dike flood protection system. To do so, a simplified model of vertical marsh accretion was combined with the SWAN wave model and a probabilistic evaluation of dike failure by overtopping. The modelled foreshore, hydraulic conditions, and dike design were taken from the Ems estuary in the Dutch Wadden sea as a case-study. Through this modelling system, the required dike reinforcement over time as a result of human interventions and dynamic processes in the marsh was explored.

\section{Marsh Processes and Flood Protection}

\subsection{Marsh Development and Human Influence}

Salt marshes are coastal ecosystems on the fringes of land and sea. Vegetation within the marsh has adapted to frequent submergence by the tide. Typically, the edge of marshes can be found above mean high neap tide (MHNT), where submergence times are tolerable only for the most well-adapted plants [9]. When tides inundate the marsh, the vegetation exerts a drag force on the water, decelerating the flow. In the decelerated flow, sediment suspended in the water can settle while the turbulent motions of waves are dampened [10,12,24]. Furthermore, the root structure reinforces the soil, making the soil more resistant to erosion [25]. As a result, the marsh platform accumulates sediment over time and grows in elevation, allowing for a succession of plants less tolerant to submergence on the higher elevations [9]. That way, the pioneering plants in the ecosystem "engineer" their environment to facilitate the establishment of more vegetation [26].

Sea-level rise directly affects the water level, and through the interactions described above, would affect the development of a marsh. The resilience of marshes to sea-level rise is highly debated in literature. Crosby et al. [27] predict as many as $60 \%-90 \%$ of marshes globally are under threat of drowning this century. Spencer et al. [28] estimated a loss of $46 \%-78 \%$, and Craft et al. [29], $20 \%-45 \%$. Schuerch et al. [30] predicts only $0 \%-30 \%$ of global wetlands will be lost if no new accommodation space for marsh is created. Kirwan $[13,14,31,32]$ explained that key determinants of marsh resilience are the rate of sea-level rise, tidal range, the amount of sediment suspended in the coastal water, and the capacity of marshes to retreat to higher elevations. Without considering the feedback between these processes, the resilience of marshes can be greatly underestimated [31]. Other studies [18,33,34] point out that marshes can still be lost by lateral erosion from increased wave action, even if vertical accretion of the marsh surface supersedes the rate of sea-level rise. 
Human actions in the larger delta system play a crucial role in the development of marshes. Land reclamation has already resulted in a direct loss of roughly one third of coastal wetlands, including marshes, worldwide [35]. However, human interventions can affect a marsh further by disrupting the flow of sediment. For instance, the expansion of marshes in the Yangtze delta has been halted or turned to retreat as a result of dams being constructed upstream, blocking the flow of sediments to the coast [21,36]. Meanwhile, the retreat of marshes on Sturgeon Bank, Vancouver, B.C., Canada, has been caused in part by the reduction in sediment supply as a result of dredging in the Fraser River and the redirection of its outflow by a jetty [37]. In Jamaica bay, New York City, US, mineral sediment supply was reduced by $60 \%$ in the past two centuries due to urbanisation, but sediment supply was compensated by enhanced organic deposition after intense fertilization of the marsh by wastewater pollution [38]. Ironically, improving water quality in Jamaica bay would probably lead to a reduced resilience of its marshes to sea-level rise. Other such examples of human interventions are numerous, and reveal the extent of the influences these can have [32].

In the light of historic marsh losses, preserving or restoring marsh habitat for coastal protection has become increasingly important. Measures have been employed to restore marsh land like, e.g., de-poldering of agricultural land [39], applying sediment onto or near tidal flats [40,41], and promoting sedimentation with groynes or dams [42]. While these interventions aim to restore and/or preserve marsh habitat, these projects can also aid in flood protection.

\subsection{Flood Protection Services by Marshes}

Flood protection measures aim to reduce the risk of areas being inundated. Structures like dikes fail when the hydraulic load is too great to prevent water (pressure) from: flowing over the dike (i.e., overflow and overtopping), eroding or destabilising the structure resulting in collapse (e.g., macro-stability and erosion), or causing excessive seepage in the ground below (i.e., piping). The hydraulic load is composed of characteristics of the extreme event: the water level, wave characteristics, storm duration, etc. Flood protection services are provided when the marsh interacts with one or more components of the hydraulic load.

The attenuation of waves by a marsh is one of the benefits for flood protection. Many studies have found significant wave height reductions within the first 10s of metres of marsh [10,16,43-45]. Waves are dampened further with distance travelled across the marsh. Möller et al. [10] measured 60\% of the wave height reduction during storm surges could be attributed to the plants themselves. Studies tend to highlight the large reductions achieved with wave heights below $1 \mathrm{~m}$ and biomass under peak summer conditions. Field studies have found a strong seasonality in wave attenuation corresponding to seasonal changes in vegetation density $[16,45,46]$. Vuik $[23,47]$ showed that the capacity of marshes to attenuate waves is hampered by the breaking of stems under high wave loads. Moreover, field studies have consistently shown that the wave dampening capacity diminishes when the marsh is considerably inundated $[16,48,49]$. Well-known models of wave dampening by vegetation predict a continuously stronger decrease in drag-force from vegetation as the inundation depth exceeds the height of the vegetation [50-52]. Taken together, the direct effect of wave dampening by the presence of vegetation during extreme events becomes limited, once storm surges are expected to be substantially higher than mean high tide (MHT) and typical wave heights are sufficient to break all stems remaining in winter.

Another benefit of coastal wetlands is storm surge attenuation. A recent review of attenuation rates by Glass et al. [53], suggests marshes can attenuate water levels about 4 to $5 \mathrm{~cm} / \mathrm{km}$, with extremes reported at -2.2 and $70 \mathrm{~cm} / \mathrm{km}$. Stark et al. [54] explained that the ability of marshes to attenuate water levels is determined by the combination of friction effects along the tidal channels and their convergence. Models suggest a small and shallow tidal channel system will result in more attenuation than one with wide, deep channels [55]. Attenuation is strongest for surges up to about $1 \mathrm{~m}$ above the marsh platform and diminishes with higher inundation levels and longer lasting events $[54,56]$. Furthermore, the presence of dikes or levees reduces the attenuation, as they block the water from 
moving further inland. Consequently, the mash platform inundates faster and the rate of storm surge attenuation reduces [55].

The highest value of marshes for coastal protection during extreme events lies instead in the ability of marshes to grow in elevation over time, thereby limiting the water depth waves can travel through before reaching the flood defence. Waves break and dissipate energy when the water depth decreases sufficiently [57]. Thus, as long as the marsh accretes faster than the rate of sea-level rise, wave heights at the flood defence can be expected to diminish over time. Furthermore, during storm events, strong winds actively generate waves across the inundated tidal flats and marshes. The wave height generated by the wind is limited by the water depth [58]. The effect of marsh accretion, thus, diminishes both the generation and progression of waves on the marsh platform.

\section{Methods}

\subsection{Case-Study Description}

The interplay between flood protection, nature conservation, and human interventions within a delta system is one of the challenges in the Ems-Dollard estuary, The Netherlands (Figure 1). Over centuries, a large portion of the marshland was converted into farmland until the final reclamation in 1924 [59]. Accretion of the marsh was still promoted with a system of ditches and clay dams until the 1950s, when maintenance of the ditches and dams ceased. Since then, the marsh has shown an overall retreat $[59,60]$. Today, the marshes are part of a protected nature reserve, with sections that are privately owned and used for grazing livestock.

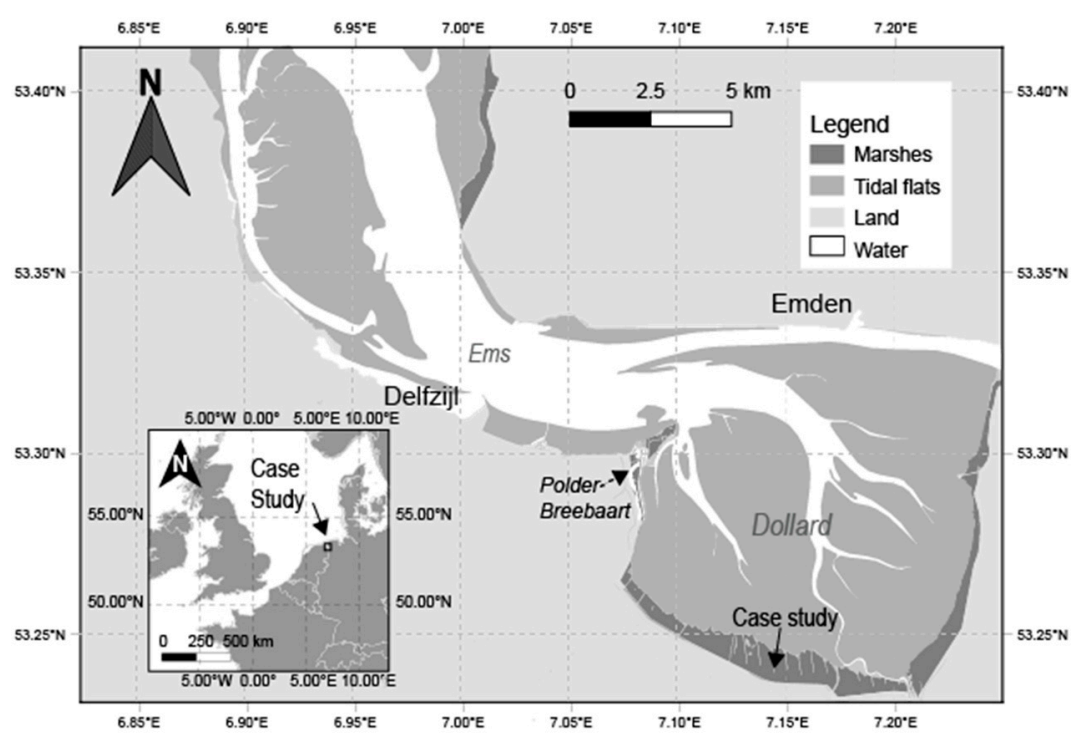

Figure 1. The case-study site in the Dollard within the Dutch Ems estuary. The map was adapted from OpenStreetMap@ layers.

The loss of major sediment sinks like marshes, the frequent dredging of the shipping lanes and harbours, and morphological processes within the estuary itself, have resulted in a high turbidity in the estuary. Over the past 20 years, the mean annual sediment concentration has increased between 0.7 to $4 \mathrm{mg} / \mathrm{L}$ annually [61], and without intervention, a further increase is likely.

The high turbidity is of concern for the local ecological quality of the estuary, as the turbid water negatively affects the primary production of the ecosystem. It was, therefore, decided by the provincial government to remove $1 \mathrm{Mt}$ of sediment per year from the estuary by 2050 [62]. Measures proposed to do so include creating and maintaining sediment sinks like de-poldered Polder Breebaart, creating a sediment sink between the twin dikes at Delfzijl, and by digging borrowing pits in the current marsh itself that refill from sediment in the estuary within the Wide Green Dike project. The new 
sediment sinks are used as nature reserves, while borrowing pits are dug such that these create islands for birds to breed undisturbed. Furthermore, a pilot is being conducted to process clay dredged from the local harbour at Delfzijl and the clay periodically extracted from the marshes as material for dike construction.

The goals of these projects are threefold: (1) to improve the water quality in the estuary to acceptable levels by reducing turbidity, (2) to create new or enhance existing natural values with marshes, and (3) to retrieve building material for future dike reinforcements. The dynamics of the marsh-foreshore are affected by the interventions in the sediment dynamics of the system. In turn, changes in the foreshore will affect the hydraulic load on the dike. Furthermore, both the marshes and the dikes will be affected by sea-level rise in the future. This complicates assessing the extent to which the dikes should be reinforced to combat sea-level rise, while these other processes are at play. Therefore we investigated in this study how sensitive the required dike reinforcement against sea-level rise will be to a combination of effects, including the changes in the system mentioned above.

\subsection{Model Framework}

To explore the sensitivity of the required dimension of the dikes along the Dollard to sea-level rise and other interventions in the estuary, we look at a simple representation of one dike and marsh cross-section. The hydraulic forcing at the marsh edge was adapted from Rijkswaterstaat's hydraulic boundary conditions database for the detailed dike assessments of the Wadden Sea [63] and analysed it with the statistical model for the Dutch coast Hydra-NL [64]. A constant slope of $1 / 4000$ across the Dollard marsh was determined from the AHN2 elevation map [65] and a representative width of the marsh of $750 \mathrm{~m}$. We did not consider the attenuation of storm surges or the attenuation of waves by stems of vegetation, and instead focused solely on the effect of marsh accretion, as wave heights and marsh inundation are expected to be too severe under design storm conditions (see Table 1 and Section 3.5) for a significant influence.

Table 1. Return periods of inundation depth $(d)$, significant wave height $\left(H_{s}\right)$ and wave peak period $\left(T_{p}\right)$ at the edge of the Dollard marshes, as calculated with Hydra-NL.

\begin{tabular}{cccc}
\hline Return Period [yr] & $\boldsymbol{d}$ & $\boldsymbol{H}_{\boldsymbol{s}}[\mathrm{m}]$ & $\boldsymbol{T}_{\boldsymbol{p}}[\mathrm{s}]$ \\
\hline 10 & 2.78 & 1.34 & 4.14 \\
100 & 3.69 & 1.85 & 4.90 \\
1000 & 4.47 & 2.35 & 5.52 \\
10,000 & 5.18 & 2.85 & 6.05 \\
100,000 & 5.84 & 3.37 & 6.52 \\
\hline
\end{tabular}

We employed a similar approach as that used in Marijnissen et al. [66] to determine dike dimensions in a wide green dike system. The accretion of the marsh by suspended sediment was simulated under a constant sea-level rise rate (Processes 1 and 2 in Figure 2; see Section 3.3) for a 20 year period. Within this relatively short morphological period both sediment concentration and sea-level rise are assumed to remain constant. The SWAN wave model [67] was run under a variety of wind, wave, and water-level conditions to calculate the expected wave attenuation by the foreshore (see Section 3.4). From here, an optimal dike crest height was determined (see Section 3.5). The foreshore was then adapted with the modelled amount of accretion and the amount of marsh retreat in the scenario. The wave attenuation under the sea-level rise conditions and altered foreshore was recalculated and used to calculate new dike dimensions (see Section 3.4). From this we estimated the required rate of dike reinforcement under a particular scenario. 


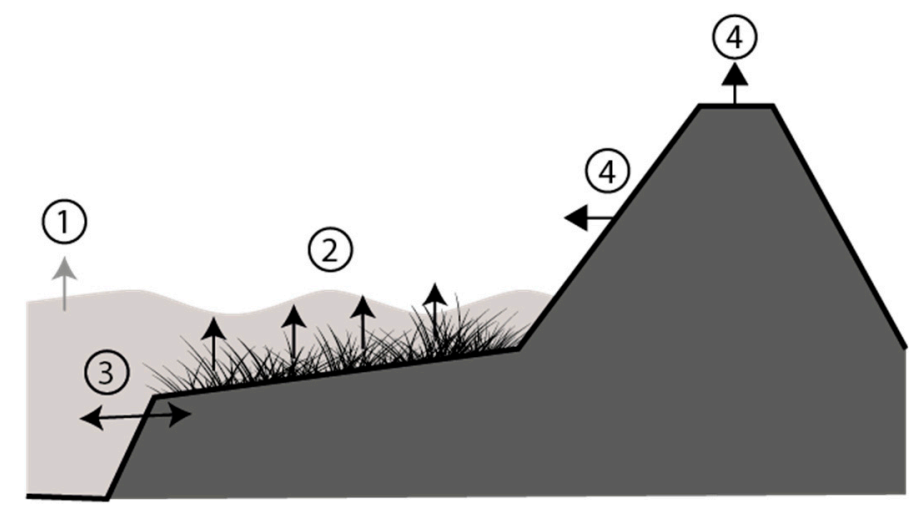

Figure 2. The processes modelled within the framework. (1) Sea-level rise, (2) vertical sediment accretion and compaction, (3) marsh retreat, and (4) dike reinforcement.

We varied four parameters: the rate of sea-level rise, the suspended sediment concentration, the rate of marsh retreat, and the bulk dry density in the marsh (see Table 2). Each represents expected or already observed processes affecting the Dollard marshes. The rates of sea-level rise were chosen between 3 and $20 \mathrm{~mm} / \mathrm{y}$ to cover the range of sea-level rise rates for the Wadden Sea in RCP scenarios for this century [68]. The suspended sediment concentration was taken from the study of the wide green dike [66] and halved or doubled to cover a wide range of potential futures and measures affecting the sediment supply. The marsh edge retreat rate was based on a scenario of marsh conservation and/or no retreat, and rates of 1 and $2 \mathrm{~m} / \mathrm{yr}$ of retreat. Observed rates of retreat average between +0.4 and $-1.7 \mathrm{~m} / \mathrm{yr}$ [69]. Finally, we consider different marsh management scenarios based on the three classes of sediment density found in the marsh [66]. A value of $398 \mathrm{~kg} / \mathrm{m}^{3}$ represents no compaction or little compaction, $873 \mathrm{~kg} / \mathrm{m}^{3}$ represents compaction under the current management with grazing of the marsh, and $1208 \mathrm{~kg} / \mathrm{m}^{3}$ represents heavy compaction from extensive use of the marsh with heavy equipment. In total, 108 combinations of these parameters were run for analysis.

Table 2. The parameters affecting the marsh and dike varied in this study.

\begin{tabular}{cccc}
\hline Variable & Description & Values & Unit \\
\hline SLR & Sea-level rise rate & $3,5,10,20$ & $\frac{\mathrm{mm}}{\mathrm{yr}}$ \\
SSC & Suspended sediment concentration & $0.1,0.2,0.4$ & $\frac{\mathrm{kg}}{\mathrm{m}^{3}}$ \\
MR & Marsh edge retreat & $0,1,2$ & $\frac{\mathrm{m}}{\mathrm{yr}}$ \\
BDD & Bulk dry density of sediment & $398,873,1208$ & $\frac{\mathrm{kg}}{\mathrm{m}^{3}}$ \\
\hline
\end{tabular}

\subsection{Vertical Marsh Accretion}

A basic sedimentation model was applied to simulate accretion of the marsh. It was simplified from existing numerical models of marsh accretion under sea-level rise conditions [70-72]. The model is a balance between the total load of sediment above the marsh platform, the amount of sediment deposited, and elevation change. Every time the water exceeds the elevation of the marsh platform $\left(z_{\text {marsh }}\right)$, a water column with a concentration of suspended sediment $\left(C_{\text {flood }}\right)$ is present. A fraction of suspended sediment deposits $\left(f_{d}\right)$ and settles with a certain density $\left(\rho_{\text {deposit }}\right)$ on the marsh. Here, $f_{d}$ is a simplified constant combining the effects of sediment fall velocity, tidal asymmetry, and erosion. It was calibrated using observed deposition rates between 1984 and 2003 [60,73]. The high waters from the nearby tide gauge station at Nieuw Statenzijl $\left(h_{H W}\right)$ were analysed and the expected number of inundations with each water level per year was computed $\left(n_{\text {events }}\right)$. Sea-level rise is incorporated by raising the water-level at each inundation frequency by the total amount of sea-level rise. Summing the deposition during each water level and subtracting subsidence results in the net elevation change 
for a given year (Equation (1)). Details on the parameters and probability distributions can be found in Appendix A.

$$
\frac{d z}{d t}=\sum_{i=1}^{n} \frac{n_{\text {event }, i^{*} C_{f l o o d}}\left(h_{H W, i}-z_{\text {marsh }}\right) * f_{d}}{\rho_{\text {deposit }}}-s_{\text {subsidence }} .
$$

\subsection{Wave Forcing and Attenuation by the Foreshore}

The SWAN wave model was used to compute wave attenuation across the foreshore [67]. It incorporates the effects of wave breaking, the influence of the wind, and bottom friction. The friction across the marsh platform was incorporated as a bottom roughness with a Manning coefficient of $0.02 \mathrm{~m}^{-1 / 3} \mathrm{~s}$ representing flats under worst-case open-water conditions [56].

The water level, wave, and wind conditions at the marsh edge were retrieved from Rijkswaterstaat's hydraulic database for foreshores in the Wadden Sea [63] and processed with Hydra-NL (see Table 1).

For each of the 108 scenarios over 600 different combinations of wave height, period, water level, and wind speed with exceedance probabilities between $10^{-0.1}$ to $10^{-6} \mathrm{yr}^{-1}$ were run across the foreshore. The results were stored in a database. Only waves and winds from the north-west along the strait connecting the Dollard to the Wadden Sea were considered because, owing to the orientation of the Dollard (see Figure 1), only those could result in the critical storm surges and wave heights. The generated database of SWAN computations was used to interpolate arbitrary combinations of wave, wind, and water levels in front of the marsh into hydraulic parameters at the dike toe without the need to rerun the SWAN model itself. This sped up the iterative dike failure computation (see Appendix B) which requires in the order of $100 \mathrm{~s}$ of evaluations of the attenuation provided by foreshore under changing hydraulic parameters to compute the failure probability of the dike under a specific scenario.

\subsection{Dike Reinforcement Calculation}

Dikes needs to be high enough to limit the risk of waves eroding the dike by overtopping to an acceptable level. For dikes along the Dollard the safety level for dike failure is $1 / 4000 \mathrm{yr}^{-1}$. As dikes can fail by multiple mechanisms across the length of the transect, a correction factor needs to be applied when evaluating a cross-section of a specific failure mechanism. In accordance with the Dutch guideline "Designing with flooding probabilities" [74] the acceptable level of overtopping for a given cross-section should be approximately $1 / 200,000 \mathrm{yr}^{-1}$.

The amount of wave overtopping is computed with the formulas in the Eurotop manual [75]. The dike is considered to have failed when the amount of overtopping exceeds the critical amount of overtopping to initiate erosion (see Appendix A for parameter values and Appendix B for the formulas). The risk of such a failure was calculated with the first order reliability method (FORM) algorithm by Low and Tang [76] implemented in the non-linear optimizer "fmincon" in the numerical analysing software MATLAB. The procedure iteratively searches the likeliest set of input parameters where failure is initiated. The dike crest height was varied and evaluated with the FORM algorithm until a crest height was found meeting the safety standard (see Appendix B for details). In this manner, a crest height was computed for each of the 108 scenarios with varying sea-level rise, suspended sediment concentration, marsh retreat rate, and foreshore compaction. The reinforcement is simply the difference between the required crest height at the end of the 20-year scenario and the start of the scenario.

\section{Results}

The required rates of dike reinforcement for all different combinations of bulk dry density (BDD), suspended sediment concentration (SSC), sea-level rise (SLR), and marsh retreat scenarios (MR) (see Table 2) are shown in Figure 3. Intuitively, one would expect that for every millimetre of sea-level rise requires an equivalent amount of dike reinforcement would be necessary. The difference between the rate of sea-level and the year-averaged amount of dike heightening required $\left(\Delta R_{\text {crest }}\right)$ depends on 
the relative amount of marsh accretion and retreat compared to sea-level, resulting in more or less attenuation of waves.

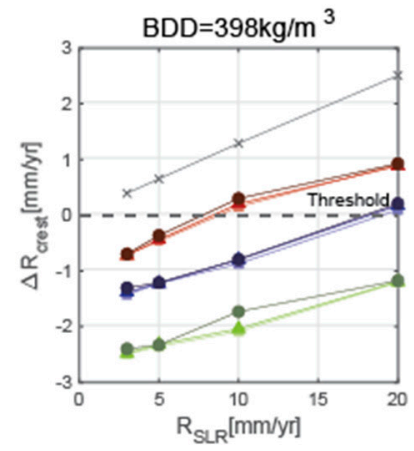

(a)

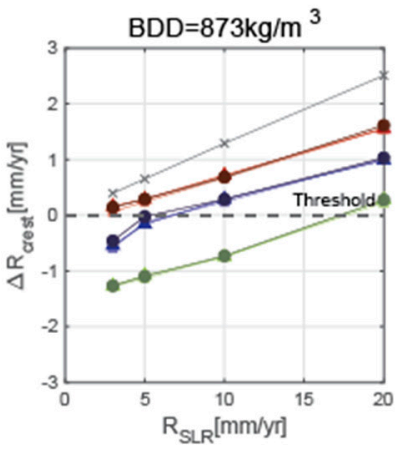

(b)

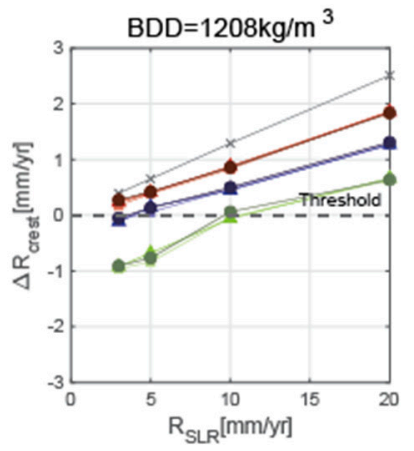

(c)

Figure 3. The year-averaged dike heightening rate $\left(\Delta R_{\text {crest }}\right)$ on top of sea-level rise $\left(R_{S L R}\right)$ for the Dollard in the Dutch Wadden sea. The grey line represents a static foreshore without any morphological changes. The coloured lines represent sediment concentrations. The marsh retreat rate scenarios are denoted by the symbols and variations in shade of colour. The dashed black line at $\Delta R_{\text {crest }}=0$ is the threshold, above which the year-averaged rate of dike reinforcement exceeds the anticipated rate of sea-level rise.

To infer the sensitivity of the dike reinforcement rate to the changes, a linear model (LM) was fit to the results in the form of:

$$
\left(R_{\text {crest }}-R_{S L R}\right)=a_{S L R} * R_{S L R}+a_{C \text { flood }} * C_{\text {flood }}+a_{\text {marsh }} * R_{\text {marsh }}+a_{B D D} * \rho_{\text {deposit }}+b,
$$

where $R_{\text {crest }}$ is the required rate of dike heightening; $R_{S L R}$ is the rate of sea-level rise; $R_{\text {marsh }}$ is rate of marsh retreat; $\rho_{\text {deposit }}$ is the density of deposited sediment; $a_{S L R}, a_{C \text { flood }}, a_{\text {marsh }}$, and $a_{B D D}$, represent the local sensitivity to each of these variables; and $b$ is a model constant. The threshold, above which dike reinforcement outpaces sea-level rise, is found by rearranging Equation (2) as follows:

$$
R_{S L R, \text { crit }}=\frac{-a_{\text {Cflood }} C_{\text {flood }}-a_{\text {marsh }} R_{\text {marsh }}-a_{B D D} \rho_{\text {deposit }}-b}{a_{S L R}} .
$$

First of all, the least-squares fit of the sensitivity parameters $a$ and constant $b$ approximates the solutions of the modelling procedure well (Table 3). This suggests that at least for this specific case-study, a LM is sufficient to describe the influences between the dike reinforcement rate, the rate of sea-level rise, sediment concentration in the estuary, and the average density of deposited soil on the foreshore for the immediate future (up to 20 years). From the LM, it is substantially easier to infer the relative influences of the future processes on dike reinforcement.

\begin{tabular}{|c|c|c|c|}
\hline & Estimate & 95\% Confidence Range & Unit \\
\hline$a_{S L R}$ & $8.76 \times 10^{-2}$ & $8.2 \times 10^{-2}-9.4 \times 10^{-2}$ & - \\
\hline$a_{\text {Cflood }}$ & $-4.90 \times 10^{-3}$ & $-5.2 \times 10^{-3}--4.6 \times 10^{-3}$ & $\frac{\mathrm{m}^{4}}{\mathrm{~kg} * \mathrm{vr}}$ \\
\hline$a_{\text {marsh }}$ & $3.13 \times 10^{-5}$ & $-1.8 \times 10^{-5}-8.0 \times 10^{-5}$ & - \\
\hline$a_{B D D}$ & $1.60 \times 10^{-6}$ & $1.5 \times 10^{-6}-1.7 \times 10^{-6}$ & $\frac{\mathrm{m}^{4}}{\mathrm{~kg} * \mathrm{Vr}}$ \\
\hline$b$ & $-1.23 \times 10^{-3}$ & $-1.4 \times 10^{-3}--1.1 \times 10^{-3}$ & $\frac{\mathrm{m}}{\mathrm{yr}}$ \\
\hline \multicolumn{4}{|c|}{ Goodness of Fit: } \\
\hline$R^{2}$ & 0.96 & & - \\
\hline RMSE & $2.1 \times 10^{-4}$ & & $\frac{\mathrm{m}}{\mathrm{yr}}$ \\
\hline
\end{tabular}

Table 3. Fitted parameters of the linear model of Equation (2). See text for meaning of symbols. 
There is only a small effect expected from erosion of the marsh edge on failure of the dike by overtopping at its current width of $750 \mathrm{~m}$. This is clearly visible in Figure 3 and in the $p$-value computed for the marsh width in the linear regression $(p=0.21)$ of Table 2. A $p$-value higher than $5 \%$ from the $t$-test is not sufficient to accept the hypothesis that marsh retreat has an influence on future dike reinforcement. Interpreted physically, the marsh width remains sufficient to dampen waves close to its full potential under extreme conditions for the foreseeable future, in spite of the marsh receding.

In the current situation of the Dollard with an average $0.2 \mathrm{~kg} / \mathrm{m}^{3}$ suspended sediment concentration (SSC), $1 \mathrm{~m} /$ year erosion of the marsh edge, and a bulk dry density on the foreshore of $873 \mathrm{~kg} / \mathrm{m}^{3}$, the critical rate of sea-level rise for dike reinforcement is estimated to be $8.9 \mathrm{~mm} / \mathrm{yr}$. The sediment concentration is, thus, contributing substantially to mitigating future dike reinforcements. Halving the SSC $0.1 \mathrm{~kg} / \mathrm{m}^{3}$ reduces the critical rate of sea-level rise to only $3.3 \mathrm{~mm} / \mathrm{yr}$ while a doubling of SSC to $0.4 \mathrm{~kg} / \mathrm{m}^{3}$ increases it to $20 \mathrm{~mm} / \mathrm{yr}$. In other words, halving or doubling of the present-day suspended sediment concentration determines whether dike reinforcement needs to accelerate beyond sea-level rise in the near future, or only at sea-level rise rates found in the highest projections.

The range of bulk dry densities tested had a large influence on the results. While in the current situation the critical rate of sea-level rise was found to be $8.9 \mathrm{~mm} / \mathrm{yr}$, if in the future compaction of the foreshore would be limited to $400 \mathrm{~kg} / \mathrm{m}^{3}$, the critical rate of sea-level rise moves to $17.6 \mathrm{~mm} / \mathrm{yr}$. On the other hand, if in an extreme case human activity would fully compact the foreshore to $1200 \mathrm{~kg} / \mathrm{m}^{3}$ present-day, sea-level rise would already result in a dike reinforcement rate higher than sea-level rise. Changing management to limit compaction $\left(400 \mathrm{~kg} / \mathrm{m}^{3}\right)$ or allow almost full compaction of the clay $\left(1200 \mathrm{~kg} / \mathrm{m}^{3}\right)$ on the foreshore is roughly equivalent to doubling or halving SSC on the marshes for the rate of dike reinforcement.

\section{Discussion}

The question this paper set out to explore was how influential the dynamics of a natural foreshore are for future reinforcements of a dike-wetland system. The results of the Dollard case-study show that interventions altering the supply of sediment and management of the foreshore strongly affect the rate of dike reinforcement. There are examples of cases where the sediment supply has been halved [36] and marsh soil was strongly compacted after extensive agricultural use [77]. Effective adaptation, thus, should strongly consider the impact of other uses on the foreshore and developments within the delta that could affect the sedimentary processes of the marsh.

The focus on sedimentary processes exclusively for dike reinforcement in this case-study, rather than biological factors, is an indirect result of the extreme hydraulic loads that need to be withstood to meet the desired safety level. Under design conditions, waves of at least $2.5 \mathrm{~m}$ high and water depths over $4.5 \mathrm{~m}$ deep were expected. Because of the breaking of stems [47] and large inundation reduces both drag forces by vegetation [51] as well as the storm surge attenuation capacity [54], only the elevation created through accretion of the marsh is left as a viable contribution of the marsh. It can be expected that for other areas where the desired safety level is lower and the dike is more sheltered from extreme loads, these processes can significantly contribute to flood protection and should be incorporated for an accurate assessment.

For the case-study in the Dollard marsh, recession was not significantly affecting dike reinforcement in the foreseeable future. The $750 \mathrm{~m}$ width of the marsh is still sufficient to cope with recession. While direct dampening by stems was not included in this study, this agrees with many observations that most waves break at the edge of the marsh and further dampen decays landward [10,45,46]. According to Möller et al. [10], a width of $40 \mathrm{~m}$ is sufficient to already reduce $15 \%$ of an incoming wave's height. As our study shows, the modelled lateral dynamics of marshes do not conflict with flood protection objectives as long as a sufficient width is maintained.

The future sediment concentration, and subsequently the turbidity of the Ems-estuary, is still highly uncertain. If the water quality is improved by reducing the amount of suspended sediment, the accretion of the marshes is negatively affected and more dike reinforcement is necessary. This is not 
the full picture if the reduction in turbidity is achieved by new wetlands or borrowing pits designed to capture sediment for re-use in dike reinforcement. In that case, the measures would locally increase the required dike reinforcement from decreased sedimentation, but still aid in flood protection by capturing more sediment as a building material for use in flood protection on a larger scale.

This modelling study demonstrates the importance sediment transport towards marshes has for future dike reinforcements. Human actions like damming rivers, dredging, or building coastal infrastructure can similarly result in a lower supply [21,38], and thereby necessitate more dike reinforcement. On the flipside, adding sediment through suppletions can also be a viable addition to flood adaptation strategies $[40,41]$. The suppleted sediment has to accumulate on the marsh for longer time-scales and not degrade other areas of the system [40,78]. Doing so effectively requires extensive knowledge of the local hydrodynamics and morphology. Baptist et al. [40] mentioned the Dollard as a location where suppletion would be possible, but undesirable for water quality objectives. Furthermore as Vuik et al. [6] noted, while promoting the process of sediment accretion in the marsh decreases the probability of failure of the flood defence, artificial break waters in the marsh can still be more cost-effective in the short-term. Suppletion would, therefore, not be a preferred option for the Dollard.

Finally, this study also suggests compaction of the marsh by human use affects dike reinforcements in the future. While we did not investigate what types of uses or processes in the marsh contribute to compaction of the marsh, it is reasonable to posit that limiting compaction within the marsh will improve the resilience of both the marsh and dike system to sea-level rise. Grazing on the marsh is one such process that contributes to compaction. Studies did find higher compaction and overall shorter vegetation at grazed sites, but are yet to find a statistically significant difference in accretion rates between grazed and ungrazed sites $[79,80]$. Spatial processes affecting the distribution of sediments across the marsh were found to be more important for accretion rates than grazing [80]. A better site-specific understanding of grazing, compaction, and accretion processes is needed for assessing the impacts of grazing specifically for a flood protection strategy.

The modelled results of this study show that sea-level rise will necessitate dike reinforcements under the conditions modelled. Extrapolating the LM of the Dollard beyond its range suggests that an increase of SSC to only $0.7 \mathrm{~kg} / \mathrm{m}^{3}$ is sufficient to fully mitigate the effects of the present-day sea-level rise for flood protection through marsh accretion. Regardless of whether a tripling of SSC is physically feasible, it would conflict with the ambitions to improve the water quality by reducing SSC. Many marshes are inundated with lower a SSC than found in the Dollard. Therefore, it is infeasible that marshes alone will be sufficient to mitigate the increasing flood risk from sea-level rise. Instead of a replacement for traditional reinforcement measures, marshes act as buffers for the effects of sea-level rise, while simultaneously providing valuable services to the ecosystem.

Apart from the marsh component, the modelling approach we used to assess hydraulic loads, and overtopping is widely accepted for analyses of dikes in the Netherlands [81]. The modelled marsh behaviour was, however, simplified to a large degree. Important spatial morphological processes and features were omitted, such as resuspension and erosion events, creek formation, vegetation growth and distribution, and the feedback between these spatial processes. Superior models exist that resolve these interactions, and the approach of this study should only be considered an exploration. Feedback like that described in Mariotti and Fagherazzi [33] could accelerate recession. Furthermore, rare events could result in a sudden, large-scale die-off of marshland, affecting its evolution over time (e.g., a year of extensive herbivory or a significant storm event). Nevertheless, simple models still tend to be the most suitable for a simple exploration of the general behaviour of wetlands [82].

\section{Conclusions}

In recent years, it has been recognized that marsh ecosystems play a role in flood protection, because of their wave- and storm surge attenuation properties. Few studies, however, quantified the processes affecting marshes in relation to the challenge of reinforcing defences against sea-level rise. 
Studies from the past two decades focussed on three main contributions of marshes to flood protection: (1) wave attenuation by vegetation, (2) storm surge attenuation, and (3) stabilisation and accretion of foreshores. Accretion of foreshores directly counter-acts the effects of sea-level rise on the propagation of waves. Wave attenuation by vegetation and storm surge attenuation by marshes are hampered during high storm surges with high wave heights. Therefore, accretion is the most important process to consider in flood protection schemes. Furthermore, anecdotal evidence from literature reveals that the sediment supply needed for accretion can be greatly influenced by human actions in the delta.

A simple marsh accretion model of the Dollard marsh-dike system was combined with the design procedures for dikes to explore the effects of sediment supply, marsh retreat, and marsh compaction on sea-level rise adaptation schemes. At present day conditions, a sea-level rise exceeding $8.9 \mathrm{~mm} / \mathrm{yr}$ would require dikes to be heightened at a faster pace than the rate of sea-level rise. Halving the supply of sediment to the marsh reduces the threshold to a sea-level rise rate of $3.3 \mathrm{~mm} / \mathrm{yr}$ while doubling the sediment supply increases that to $20 \mathrm{~mm} / \mathrm{yr}$. Similarly, if the bulk dry density of the deposited soil is to remain low, this threshold will be at $17.6 \mathrm{~mm} / \mathrm{yr}$, while if the soil is highly compacted by human activity, marsh accretion would already be insufficient at present day sea-level rise. In short, either halving or doubling of the present-day suspended sediment concentration, or from managing the foreshore that leads to high or low compaction of the marsh, determines whether dike reinforcement needs to accelerate beyond sea-level rise in the near future, or only at sea-level rise rates found in the highest projections

Our results and modelling approach are also interesting for other regions. While the focus of flood risk adaptation schemes is usually on sea-level rise itself, the results of this study show there is a great deal of influence people have on the extent of future dike reinforcements through the management of marshes.

Author Contributions: Conceptualization, R.M., J.v.L.-S., and M.K.; methodology, R.M.; writing一original draft preparation, R.M.; writing—review and editing, J.v.L.-S., M.K., and C.K.; visualization, R.M.; supervision, J.v.L.-S., M.K, and C.K.; project administration, J.v.L.-S.; funding acquisition, J.v.L.-S. and M.K. All authors have read and agreed to the published version of the manuscript.

Funding: This work is part of the Perspectief research programme All-Risk with project number P15-21, which is financed by NWO Domain Applied and Engineering Sciences.

Acknowledgments: We would like to thank Erik Jolink from the water board Hunze en Aa's and project leader of the Wide Green Dike project for his help and collaboration that made this research possible. We would further like to thank Peter Esselink for sharing his knowledge and experience with the Dollard marshes to the authors. Finally, we want to thank the two anonymous reviewers for their comments that improved the manuscript.

Conflicts of Interest: The authors declare no conflict of interest.

\section{Appendix A. Model Parameters}

Table A1. Marsh accretion parameters.

\begin{tabular}{cccc}
\hline Variable & Description & Value & Unit \\
\hline$h_{H W}$ & Distribution of the water level at high tide & $\mathrm{GEV}(\mu=1.3, \sigma=0.4, \xi=-0.1)$ & $\mathrm{m}+\mathrm{NAP}$ \\
$C_{\text {flood }}$ & Suspended sediment concentration & See Table 2 & $\frac{\mathrm{kg}}{\mathrm{m}^{3}}$ \\
$f_{d}$ & Fraction of suspended sediment retained per tidal cycle & 0.8 & - \\
$\rho_{\text {deposit }}$ & Bulk dry density of the marsh & See Table 2 & $\frac{\mathrm{kg}}{\mathrm{m}}$ \\
$s_{\text {subsidence }}$ & Subsidence rate & 2.7 & $\frac{\mathrm{mm}}{\mathrm{yr}}$ \\
\hline
\end{tabular}


Table A2. Marsh profile parameters.

\begin{tabular}{cccc}
\hline Variable & Description & Value & Unit \\
\hline$z_{\text {marsh }}$ & Initial marsh elevation & 1.86 & $\mathrm{~m}+\mathrm{NAP}$ \\
$B_{\text {marsh }}$ & Initial marsh width & 750 & $\mathrm{~m}$ \\
$\tan \alpha_{\text {mars }}$ & Slope of the marsh elevation & $1 / 4000$ & - \\
\hline
\end{tabular}

Table A3. Parameters used in the dike reinforcement calculation. Distributions are GEV = generalized extreme value distribution, $\mathrm{W}=$ Weibull distribution, $\mathrm{C}=$ constant, $\mathrm{L}=$ lognormal, $\mathrm{V}=$ variable is adjusted between computations.

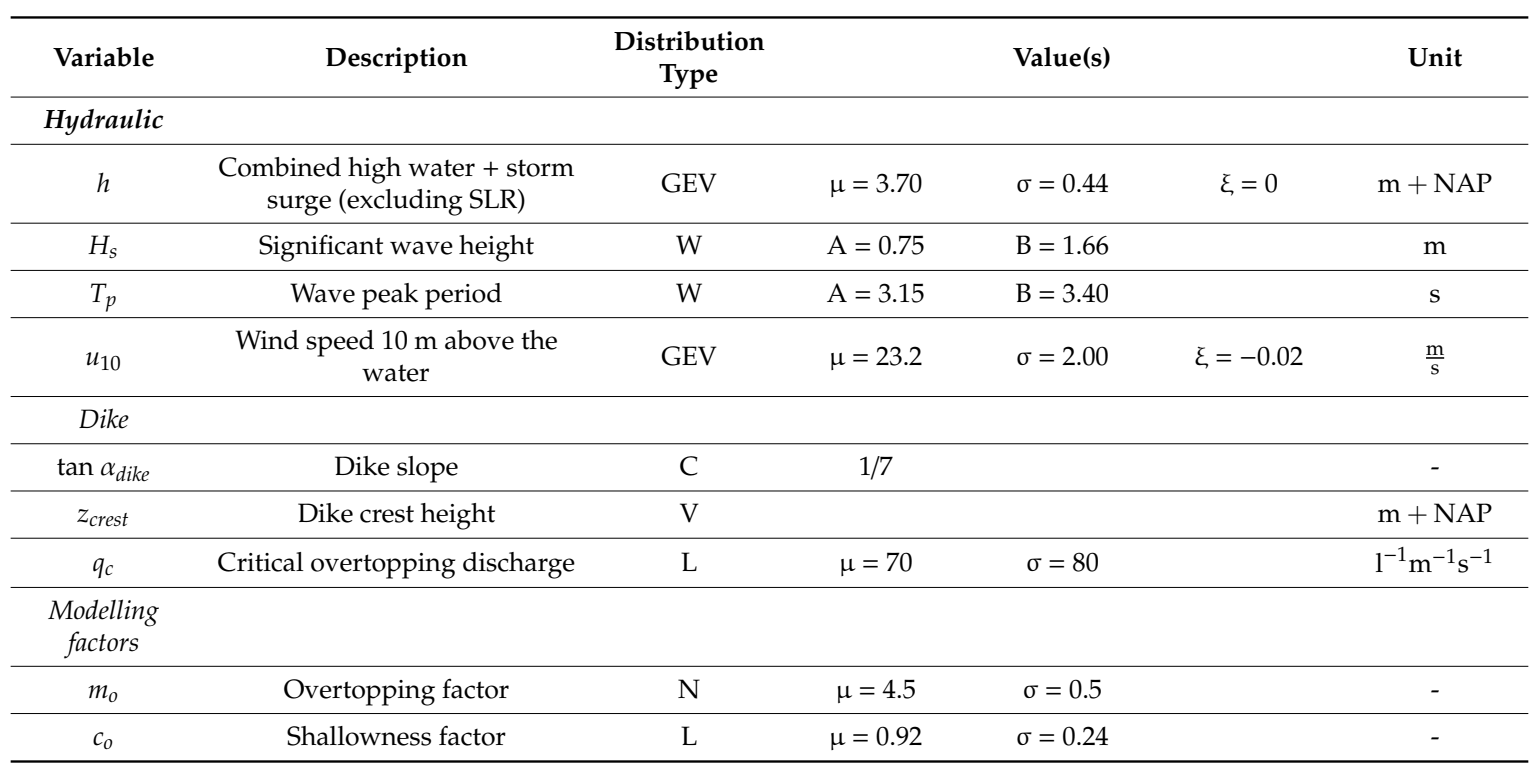

Table A4. The correlation matrix between hydraulic parameters fitted from Hydra-NL.

\begin{tabular}{ccccc}
\hline & $\boldsymbol{h}$ & $\boldsymbol{H}_{\boldsymbol{s}}$ & $\boldsymbol{T}_{\boldsymbol{p}}$ & $\boldsymbol{u}_{10}$ \\
\hline $\boldsymbol{h}$ & 1 & 0.77 & 0.56 & 0.71 \\
$\boldsymbol{H}_{\boldsymbol{s}}$ & 0.77 & 1 & 0.94 & 0.62 \\
$\boldsymbol{T}_{\boldsymbol{p}}$ & 0.56 & 0.94 & 1 & 0.39 \\
$\boldsymbol{u}_{\mathbf{1 0}}$ & 0.71 & 0.62 & 0.39 & 1 \\
\hline
\end{tabular}

\section{Appendix B. Dike Reinforcement Formulas}

\section{Appendix B.1. The Overtopping Calculation}

Before the amount of overtopping can be determined the wave, conditions at the dike toe need to be known. The SWAN wave model was used to transform offshore wave and wind conditions into a significant wave height $\left(H_{s}\right)$ and spectral wave period $\left(T_{m-1}\right)$ at the dike toe. From the database of computed SWAN transformations, new offshore conditions could be readily transformed to conditions at the dike (see Section 3.4).

The following section summarizes the procedure to calculate the average discharge of water over a dike during storm conditions following the EurOtop manual [75]. First, the type of wave breaking was determined with the breaker index $(\xi)$, a ratio between the slope steepness and wave steepness.

$$
\xi_{m-1,0}=\frac{\tan \left(\alpha_{\text {dike }}\right) * \sqrt{g T_{m-1}^{2}}}{\sqrt{2 \pi H_{S}}} .
$$


Since the spectral wave period $T_{m-1}$ was used in this variation, the breaker index has the subscript $m-1$. For $\xi_{m-1,0}<5$, the average overtopping discharge $(q)$ was calculated with the formula:

$$
\begin{aligned}
& \frac{q}{\sqrt{g H_{s}^{3}}}=\frac{0.067}{\sqrt{\tan \left(\alpha_{\text {dike }}\right)}} * \gamma_{b} * \xi_{m-1,0} * \exp \left(-m_{0} * \frac{R_{c}}{\xi_{m-1,0 * H_{s} * \gamma_{b} * \gamma_{f} * \gamma_{\beta}}}\right) \\
& \text { with a maximum of : } \frac{q}{\sqrt{g H_{s}^{3}}}=0.2 * \exp \left(-2.6 * \frac{R_{c}}{H_{s}^{*} \gamma_{f}^{*} \gamma_{\beta}}\right)
\end{aligned}
$$

When $\xi_{m-1,0}>7$ the average overtopping discharge $(q)$ is calculated as:

$$
\frac{q}{\sqrt{g H_{s}^{3}}}=10^{c_{0}} * \exp \left(-\frac{R_{c}}{\gamma_{f} * \gamma_{\beta} * H_{s} *\left(0.33+0.022 * \xi_{m-1,0}\right)}\right) .
$$

For cases where $5 \leq \xi_{m-1,0} \leq 7$ the overtopping discharge was interpolated between the two equations.

In the equations, $g$ is the gravitational acceleration constant, $R_{c}$ is the crest height above the average water level, and the $\gamma \mathrm{s}$ are various influence factors. The other input variables are explained in Table A3.

Because the dike was schematised as a smooth grass dike with no berm, $\gamma_{b}$ and $\gamma_{f}$ were both set to 1 . The influence of wave angle $\left(\beta_{\text {wave }}\right)$ is calculated with the equation:

$$
\gamma_{\beta}=1-0.0033 * \min \left(\left|\beta_{\text {wave }}\right|, 80^{\circ}\right) .
$$

The procedure so far describes the amount of overtopping, but not whether the dike fails. Failure of the dike was assumed when the overtopping discharge $(q)$ exceeded a critical threshold $\left(q_{c}\right)$. This was described by the limit state function $(Z)$ where dike failure was induced when $Z>0$.

$$
Z=q-q_{c}
$$

\section{Appendix B.2. First Order Reliability Method (FORM)}

The first order reliability method is an approach to approximate the probability of failure of a system. The type of failure considered in this study is excessive overtopping during a storm. Mathematically, failure is described by the limit state function (Equation (A5)) and the other equations of Appendix B.1.

Combining the values of all parameters into one single vector $(x)$, in the FORM algorithm the values in $x$ are iterative varied until $Z(x)=0$. However, many combinations of values in $x$ satisfy this condition. The probability of failure is determined by the combination of values in $x$ with the highest probability of occurring, given the probability distributions in Table A3 and correlations specified in Table A4. Following the FORM-method presented by Low and Tang [76], the probability of failure is approximated by first solving:

$$
\beta_{Z(\bar{x})=0} \min \left(\sqrt{n^{T} R^{-1} n}\right) .
$$

Here $\beta$ is the reliability index and $R$ is the correlation matrix. The vector $n$ is a normalization of the elements in $x$ as:

$$
n_{i}=\Phi^{-1}\left(F_{i}\left(x_{i}\right)\right),
$$

where $F_{i}$ is the cumulative distribution function from the $i$ th parameter in $x$, and $\Phi^{-1}$ is the inverse standard normal distribution. The probability of failure $\left(P_{f}\right)$ is computed from the reliability index $\beta$ as:

$$
P_{f}=\Phi(-\beta) \text {. }
$$


The mathematical problem stated in Equation (A6) is an example of a constrained non-linear optimization problem. The numerical solver called fmincon in the program MATLAB was used to numerically solve the system of equations in this appendix. This way, the probability of failure of different crest heights was computed until an optimal height was found meeting the safety standard.

\section{References}

1. Schoonees, T.; Gijón Mancheño, A.; Scheres, B.; Bouma, T.J.; Silva, R.; Schlurmann, T.; Schüttrumpf, H. Hard Structures for Coastal Protection, Towards Greener Designs. Estuar. Coasts 2019, 42, 1709-1729. [CrossRef]

2. Powell, E.J.; Tyrrell, M.C.; Milliken, A.; Tirpak, J.M.; Staudinger, M.D. A review of coastal management approaches to support the integration of ecological and human community planning for climate change. $J$. Coast. Conserv. 2019, 23, 1-18. [CrossRef]

3. Scheres, B.; Schüttrumpf, H. Enhancing the Ecological Value of Sea Dikes. Water 2019, 11, 1617. [CrossRef]

4. Temmerman, S.; Meire, P.; Bouma, T.J.; Herman, P.M.J.; Ysebaert, T.; De Vriend, H.J. Ecosystem-based coastal defence in the face of global change. Nature 2013, 504, 79-83. [CrossRef]

5. Borsje, B.W.; van Wesenbeeck, B.K.; Dekker, F.; Paalvast, P.; Bouma, T.J.; van Katwijk, M.M.; de Vries, M.B. How Ecol. Eng. can serve in coastal protection. Ecol. Eng. 2011, 37, 113-122. [CrossRef]

6. Vuik, V.; Borsje, B.W.; Willemsen, P.W.J.M.; Jonkman, S.N. Salt marshes for flood risk reduction: Quantifying long-term effectiveness and life-cycle costs. Ocean Coast. Manag. 2019, 171, 96-110. [CrossRef]

7. Leo, K.L.; Gillies, C.L.; Fitzsimons, J.A.; Hale, L.Z.; Beck, M.W. Coastal habitat squeeze: A review of adaptation solutions for saltmarsh, mangrove and beach habitats. Ocean Coast. Manag. 2019, 175, 180-190. [CrossRef]

8. Firth, L.B.; Thompson, R.C.; Bohn, K.; Abbiati, M.; Airoldi, L.; Bouma, T.J.; Bozzeda, F.; Ceccherelli, V.U.; Colangelo, M.A.; Evans, A.; et al. Between a rock and a hard place: Environmental and engineering considerations when designing coastal defence structures. Coast. Eng. 2014, 87, 122-135. [CrossRef]

9. Allen, J.R.L. Morphodynamics of Holocene salt marshes: A review sketch from the Atlantic and Southern North Sea coasts of Europe. Quat. Sci. Rev. 2000, 19, 1155-1231. [CrossRef]

10. Möller, I.; Kudella, M.; Rupprecht, F.; Spencer, T.; Paul, M.; van Wesenbeeck, B.K.; Wolters, G.; Jensen, K.; Bouma, T.J.; Miranda-Lange, M.; et al. Wave attenuation over coastal salt marshes under storm surge conditions. Nat. Geosci. 2014, 7, 727-731. [CrossRef]

11. Costanza, R.; Pérez-Maqueo, O.; Martinez, M.L.; Sutton, P.; Anderson, S.J.; Mulder, K. The Value of Coastal Wetlands for Hurricane Protection. AMBIO A J. Hum. Environ. 2008, 37, 241-248. [CrossRef]

12. van Loon-Steensma, J.M.; Hu, Z.; Slim, P.A. Modelled Impact of Vegetation Heterogeneity and Salt-Marsh Zonation on Wave Damping. J. Coast. Res. 2016, 32, 241-252.

13. Kirwan, M.; Temmerman, S. Coastal marsh response to historical and future sea-level acceleration. Quat. Sci. Rev. 2009, 28, 1801-18082. [CrossRef]

14. Kirwan, M.L.; Temmerman, S.; Skeehan, E.E.; Guntenspergen, G.R.; Fagherazzi, S. Overestimation of marsh vulnerability to sea level rise. Nat. Clim. Chang. 2016, 6, 253-260. [CrossRef]

15. van Loon-Steensma, J.M. Salt marshes to adapt the flood defences along the Dutch Wadden Sea coast. Mitig. Adapt. Strateg. Glob. Chang. 2015, 20, 929-948. [CrossRef] [PubMed]

16. Vuik, V.; Jonkman, S.N.; Borsje, B.W.; Suzuki, T. Nature-based flood protection: The efficiency of vegetated foreshores for reducing wave loads on coastal dikes. Coast. Eng. 2016, 116, 42-56. [CrossRef]

17. van Loon-Steensma, J.M.; Kok, M. Risk reduction by combining nature values with flood protection? E3S Web Conf. 2016, 7, 13003. [CrossRef]

18. Koppel, J.V.; van der Wal, D.V.; Bakker, J.P.; Herman, P.M. Self-Organization and Vegetation Collapse in Salt Marsh Ecosystems. Am. Nat. 2005, 165, E1-E12. [CrossRef]

19. Bouma, T.J.; van Belzen, J.; Balke, T.; van Dalen, J.; Klaassen, P.; Hartog, A.M.; Callaghan, D.P.; Hu, Z.; Stive, M.J.F.; Temmerman, S.; et al. Short-term mudflat dynamics drive long-term cyclic salt marsh dynamics. Limnol. Oceanogr. 2016, 61, 2261-2275. [CrossRef]

20. Aaron, S.B.; Turner, R.E. Relationships between Salt Marsh Loss and Dredged Canals in Three Louisiana Estuaries. J. Coast. Res. 1997, 13, 895-903.

21. Yang, S.L.; Ding, P.X.; Chen, S.L. Changes in progradation rate of the tidal flats at the mouth of the Changjiang (Yangtze) River, China. Geomorphology 2001, 38, 167-180. [CrossRef] 
22. Möller, I. Applying Uncertain Science to Nature-Based Coastal Protection: Lessons from Shallow Wetland-Dominated Shores. Front. Environ. Sci. 2019, 7. [CrossRef]

23. Vuik, V.; van Vuren, S.; Borsje, B.W.; van Wesenbeeck, B.K.; Jonkman, S.N. Assessing safety of nature-based flood defenses: Dealing with extremes and uncertainties. Coast. Eng. 2018, 139, 47-64. [CrossRef]

24. Leonard, L.A.; Reed, D.J. Hydrodynamics and Sediment Transport Through Tidal Marsh Canopies. J. Coast. Res. 2002, 36, 459-469.

25. Silliman, B.R.; van de Koppel, J.; McCoy, M.W.; Diller, J.; Kasozi, G.N.; Earl, K.; Adams, P.N.; Zimmerman, A.R. Degradation and resilience in Louisiana salt marshes after the BP-Deepwater Horizon oil spill. Proc. Natl. Acad. Sci. USA 2012, 109, 11234-11239. [CrossRef]

26. Bouma, T.J.; Vries, M.B.D.; Herman, P.M.J. Comparing ecosystem engineering efficiency of two plant species with contrasting growth strategies. Ecology 2010, 91, 2696-27041. [CrossRef]

27. Crosby, S.C.; Sax, D.F.; Palmer, M.E.; Booth, H.S.; Deegan, L.A.; Bertness, M.D.; Leslie, H.M. Salt marsh persistence is threatened by predicted sea-level rise. Estuar. Coast. Shelf Sci. 2016, 181, 93-99. [CrossRef]

28. Spencer, T.; Schuerch, M.; Nicholls, R.J.; Hinkel, J.; Lincke, D.; Vafeidis, A.T.; Reef, R.; McFadden, L.; Brown, S. Global coastal wetland change under sea-level rise and related stresses: The DIVA Wetland Change Model. Glob. Planet. Chang. 2016, 139, 15-30. [CrossRef]

29. Craft, C.; Clough, J.; Ehman, J.; Joye, S.; Park, R.; Pennings, S.; Guo, H.; Machmuller, M. Forecasting the effects of accelerated sea-level rise on tidal marsh ecosystem services. Front. Ecol. Environ. 2009, 7, 73-78. [CrossRef]

30. Schuerch, M.; Spencer, T.; Temmerman, S.; Kirwan, M.L.; Wolff, C.; Lincke, D.; McOwen, C.J.; Pickering, M.D.; Reef, R.; Vafeidis, A.T.; et al. Future response of global coastal wetlands to sea-level rise. Nature 2018, 561, 231-234. [CrossRef]

31. Kirwan, M.L.; Guntenspergen, G.R.; D’Alpaos, A.; Morris, J.T.; Mudd, S.M.; Temmerman, S. Limits on the adaptability of coastal marshes to rising sea level. Geophys. Res. Lett. 2010, 37. [CrossRef]

32. Kirwan, M.L.; Megonigal, J.P. Tidal wetland stability in the face of human impacts and sea-level rise. Nature 2013, 504, 53-60. [CrossRef]

33. Mariotti, G.; Fagherazzi, S. Critical width of tidal flats triggers marsh collapse in the absence of sea-level rise. Proc. Natl. Acad. Sci. USA 2013, 110, 5353-5356. [CrossRef] [PubMed]

34. Fagherazzi, S.; Mariotti, G.; Wiberg, P.L.; McGlathery, K.J. Marsh Collapse Does Not Require Sea Level Rise. Oceanography 2013, 26, 70-77. [CrossRef]

35. Mcleod, E.; Chmura, G.L.; Bouillon, S.; Salm, R.; Björk, M.; Duarte, C.M.; Lovelock, C.E.; Schlesinger, W.H.; Silliman, B.R. A blueprint for blue carbon: Toward an improved understanding of the role of vegetated coastal habitats in sequestering CO2. Front. Ecol. Environ. 2011, 9, 552-560. [CrossRef]

36. Yang, S.L.; Li, M.; Dai, S.B.; Liu, Z.; Zhang, J.; Ding, P.X. Drastic decrease in sediment supply from the Yangtze River and its challenge to coastal wetland management. Geophys. Res. Lett. 2006, 33. [CrossRef]

37. Atkins, R.J.; Tidd, M.; Ruffo, G. Sturgeon Bank, Fraser River Delta, BC, Canada: 150 Years of Human Influences on Salt Marsh Sedimentation. J. Coast. Res. 2016, 75, 790-794. [CrossRef]

38. Peteet, D.M.; Nichols, J.; Kenna, T.; Chang, C.; Browne, J.; Reza, M.; Kovari, S.; Liberman, L.; Stern-Protz, S. Sediment starvation destroys New York City marshes' resistance to sea level rise. Proc. Natl. Acad. Sci. USA 2018, 115, 10281. [CrossRef]

39. Rupp-Armstrong, S.; Nicholls, R.J. Coastal and Estuarine Retreat: A Comparison of the Application of Managed Realignment in England and Germany. J. Coast. Res. 2007, 236, 1418-1430. [CrossRef]

40. Baptist, M.J.; Gerkema, T.; van Prooijen, B.C.; van Maren, D.S.; van Regteren, M.; Schulz, K.; Colosimo, I.; Vroom, J.; van Kessel, T.; Grasmeijer, B.; et al. Beneficial use of dredged sediment to enhance salt marsh development by applying a 'Mud Motor'. Ecol. Eng. 2019, 127, 312-323. [CrossRef]

41. Ford, M.A.; Cahoon, D.R.; Lynch, J.C. Restoring marsh elevation in a rapidly subsiding salt marsh by thin-layer deposition of dredged material1Mention of trade names or commercial products does not constitute an endorsement or recommendation for use by the US Government.1. Ecol. Eng. 1999, 12, 189-205. [CrossRef]

42. van Loon-Steensma, J.M.; Slim, P.A. The Impact of Erosion Protection by Stone Dams on Salt-Marsh Vegetation on Two Wadden Sea Barrier Islands. J. Coast. Res. 2013, 29, 783-796. [CrossRef]

43. Möller, I.; Spencer, T.; French, J.R.; Leggett, D.J.; Dixon, M. Wave Transformation Over Salt Marshes: A Field and Numerical Modelling Study from North Norfolk, England. Estuar. Coast. Shelf Sci. 1999, 49, 411-426. [CrossRef] 
44. Ysebaert, T.; Yang, S.-L.; Zhang, L.; He, Q.; Bouma, T.J.; Herman, P.M.J. Wave Attenuation by Two Contrasting Ecosystem Engineering Salt Marsh Macrophytes in the Intertidal Pioneer Zone. Wetlands 2011, 31, 1043-1054. [CrossRef]

45. Schoutens, K.; Heuner, M.; Minden, V.; Schulte Ostermann, T.; Silinski, A.; Belliard, J.-P.; Temmerman, S. How effective are tidal marshes as nature-based shoreline protection throughout seasons? Limnol. Oceanogr. 2019, 64, 1750-1762. [CrossRef]

46. Möller, I.; Spencer, T. Wave dissipation over macro-tidal saltmarshes: Effects of marsh edge typology and vegetation change. J. Coast. Res. 2002, 36, 506-521. [CrossRef]

47. Vuik, V.; Suh Heo, H.Y.; Zhu, Z.; Borsje, B.W.; Jonkman, S.N. Stem breakage of salt marsh vegetation under wave forcing: A field and model study. Estuar. Coast. Shelf Sci. 2018, 200, 41-58. [CrossRef]

48. Foster-Martinez, M.R.; Lacy, J.R.; Ferner, M.C.; Variano, E.A. Wave attenuation across a tidal marsh in San Francisco Bay. Coast. Eng. 2018, 136, 26-40. [CrossRef]

49. Möller, I.; Spencer, T.; French, J.R.; Leggett, D.J.; Dixon, M. The Sea-Defence Value of Salt Marshes: Field Evidence from North Norfolk. Water Environ. J. 2001, 15, 109-116.

50. Dalrymple, R.A.; Kirby, J.T.; Hwang, P.A. Wave Diffraction Due to Areas of Energy Dissipation. J. Waterw. Port Coast. Ocean Eng. 1984, 110, 67-79. [CrossRef]

51. Mendez, F.J.; Losada, I.J. An empirical model to estimate the propagation of random breaking and nonbreaking waves over vegetation fields. Coast. Eng. 2004, 51, 103-118. [CrossRef]

52. Baptist, M.J.; Babovic, V.; Rodríguez Uthurburu, J.; Keijzer, M.; Uittenbogaard, R.E.; Mynett, A.; Verwey, A. On inducing equations for vegetation resistance. J. Hydraul. Res. 2007, 45, 435-450. [CrossRef]

53. Glass, E.M.; Garzon, J.L.; Lawler, S.; Paquier, E.; Ferreira, C.M. Potential of marshes to attenuate storm surge water level in the Chesapeake Bay. Limnol. Oceanogr. 2018, 63, 951-967. [CrossRef]

54. Stark, J.; Van Oyen, T.; Meire, P.; Temmerman, S. Observations of tidal and storm surge attenuation in a large tidal marsh. Limnol. Oceanogr. 2015, 60, 1371-1381. [CrossRef]

55. Stark, J.; Plancke, Y.; Ides, S.; Meire, P.; Temmerman, S. Coastal flood protection by a combined nature-based and engineering approach: Modeling the effects of marsh geometry and surrounding dikes. Estuar. Coast. Shelf Sci. 2016, 175, 34-45. [CrossRef]

56. Wamsley, T.V.; Cialone, M.A.; Smith, J.M.; Atkinson, J.H.; Rosati, J.D. The potential of wetlands in reducing storm surge. Ocean Eng. 2010, 37, 59-68. [CrossRef]

57. Battjes, J.A.; Stive, M.J.F. Calibration and verification of a dissipation model for random breaking waves. J. Geophys. Res. Oceans 1985, 90, 9159-9167. [CrossRef]

58. Young, I.R.; Verhagen, L.A. The growth of fetch limited waves in water of finite depth. Part 1. Total energy and peak frequency. Coast. Eng. 1996, 29, 47-78. [CrossRef]

59. Esselink, P. Nature Management of Coastal Salt Marshes: Interactions between Anthropogenic Influences and Natural Dynamics. Ph.D. Thesis, University of Groningen, Haren, Belgium, 2000.

60. Esselink, P.; Dijkema, K.S.; Sabine, R.; Geert, H. Vertical Accretion and Profile Changes in Abandoned Man-Made Tidal Marshes in the Dollard Estuary, The Netherlands. J. Coast. Res. 1998, 14, 570-582.

61. van Maren, D.S.; Oost, A.P.; Wang, Z.B.; Vos, P.C. The effect of land reclamations and sediment extraction on the suspended sediment concentration in the Ems Estuary. Mar. Geol. 2016, 376, 147-157. [CrossRef]

62. Provincie Groningen; Ministerie van Infrastructuur en Milieu. Programma Eems-Dollard 2050; Provincie Groningen; Ministerie van Infrastructuur en Milieu: Groningen, The Netherlands, 2018.

63. Rijkswaterstaat. WTI2011_Waddenzee_voorlanden.mdb. Available online: https://www.helpdeskwater.nl/ (accessed on 11 December 2019).

64. Duits, M.T.; Kuijper, B. Hydra-NL-Systeemdocumentatie-Versie 2.4.; HKV: Lelystad, The Netherlands, 2018.

65. Rijkswaterstaat. Actueel Hoogtebestand Nederland 2 (AHN2) WMS. Available online: https://geodata. nationaalgeoregister.n1/ahn2/wms?request=GetCapabilities\&service=wms (accessed on 11 December 2019).

66. Marijnissen, R.J.C.; Esselink, P.; Kok, M.; Kroeze, C.; van Loon-Steensma, J.M. How natural processes contribute to flood protection-a sustainable adaptation scheme for a wide green dike. Sci. Total Environ. Under review.

67. Booij, N.; Ris, R.C.; Holthuijsen, L.H. A third-generation wave model for coastal regions: 1. Model description and validation. J. Geophys. Res. Oceans 1999, 104, 7649-7666. [CrossRef] 
68. Vermeersen, B.L.A.; Slangen, A.B.A.; Gerkema, T.; Baart, F.; Cohen, K.M.; Dangendorf, S.; Duran-Matute, M.; Frederikse, T.; Grinsted, A.; Hijma, M.P.; et al. Sea-level change in the Dutch Wadden Sea. Neth. J. Geosci. 2018, 97, 79-127. [CrossRef]

69. Esselink, P.; Bos, D.; Oost, A.P.; Dijkema, K.S.; Bakker, R.; de Jong, R. Verkenning afslag Eems-Dollardkwelders; PUCCIMAR rapport 02, A\&W rapport 1574; PUCCIMAR Ecologisch Onderzoek \& Advies, Altenburg \& Wymenga ecologisch onderzoek: Dantumadiel, The Netherlands, 2011.

70. French, J.R. Numerical simulation of vertical marsh growth and adjustment to accelerated sea-level rise, North Norfolk, U.K. Earth Surf. Processes Landf. 1993, 18, 63-81. [CrossRef]

71. Krone, R.B. A method for simulating historic marsh elevations. In Proceedings of the a Specialty Conference on Advances in Understanding of Coastal Sediment Processes, New Orleans, LA, USA, 12-14 May 1987; pp. 316-323.

72. Allen, J.R.L. Salt-marsh growth and stratification: A numerical model with special reference to the Severn Estuary, southwest Britain. Mar. Geol. 1990, 95, 77-96. [CrossRef]

73. Esselink, P. Hoogteontwikkeling verwaarloosde landaanwinningskwelder: Opslibbing van de Dollardkwelders in de periode 1991-2003 en een vergelijking met de periode 1984-1991; Report 2007-009; Koeman en Bijkerk b.v.: Haren, The Netherlands, 2007.

74. Rijkswaterstaat. Handreiking ontwerpen met overstromingskansen; Veiligheidsfactoren en belastingen bij nieuwe overstromingskans-normen; Rijkswaterstaat: Utrecht, The Netherlands, 2017.

75. Pullen, T.; Allsop, N.; Bruce, T.; Kortenhaus, A.; Schüttrumpf, H.; Van der Meer, J. EurOtop Wave Overtopping of Sea Defences and Related Structures: Assessment Manual; EA/ENW/KFKI. Available online: http://www.overtopping-manual.com/manual.html (accessed on 15 January 2020).

76. Low, B.K.; Tang, W.H. Efficient Spreadsheet Algorithm for First-Order Reliability Method. J. Eng. Mech. 2007, 133, 1378-1387. [CrossRef]

77. Tempest, J.A.; Harvey, G.L.; Spencer, K.L. Modified sediments and subsurface hydrology in natural and recreated salt marshes and implications for delivery of ecosystem services. Hydrol. Processes 2015, 29, 2346-2357. [CrossRef]

78. Ganju, N.K. Marshes Are the New Beaches: Integrating Sediment Transport into Restoration Planning. Estuar. Coasts 2019, 42, 917-926. [CrossRef]

79. Elschot, K.; Bouma, T.J.; Temmerman, S.; Bakker, J.P. Effects of long-term grazing on sediment deposition and salt-marsh accretion rates. Estuar. Coast. Shelf Sci. 2013, 133, 109-115. [CrossRef]

80. Nolte, S.; Müller, F.; Schuerch, M.; Wanner, A.; Esselink, P.; Bakker, J.P.; Jensen, K. Does livestock grazing affect sediment deposition and accretion rates in salt marshes? Estuar. Coast. Shelf Sci. 2013, 135, $296-305$. [CrossRef]

81. Slomp, R.M.; Diemanse, F.; de Waal, H.; Stijnen, J.; Noort, J.; Wentholt, L. A consistent suite of models for flood risk management. In Proceedings of the 36th IAHR World Congress, The Hague, The Netherlands, 28 June-3 July 2015; pp. 1-5.

82. Fagherazzi, S.; Kirwan, M.L.; Mudd, S.M.; Guntenspergen, G.R.; Temmerman, S.; D'Alpaos, A.; van de Koppel, J.; Rybczyk, J.M.; Reyes, E.; Craft, C.; et al. Numerical models of salt marsh evolution: Ecological, geomorphic, and climatic factors. Rev. Geophys. 2012, 50. [CrossRef]

(C) 2020 by the authors. Licensee MDPI, Basel, Switzerland. This article is an open access article distributed under the terms and conditions of the Creative Commons Attribution (CC BY) license (http://creativecommons.org/licenses/by/4.0/). 